УДК 316.628

https://doi.org/10.34142/24130060.2020.21.2.08

\title{
ДОБРОЧИННА ДІЯЛЬНІСТЬ У СУЧАСНІЙ УКРАЇНІ: ВІД АЛЬТРУЇСТИЧНОї ДО ЕГОЇСТИЧНОї ДІї
}

\author{
О. О. Стрельнікова, Н. О. Ссіна \\ Харківський національний педагогічний університет імені Г. С. Сковороди
}

У статті розглянуто та проаналізовано особливості мотиваційної складової доброчинної діяльності у сучасному українському суспільстві. Наведено характеристику основних компонентів мотиваційної складової доброчинності, альтруїстичного та егоїстичного, у сучасній Україні. Схарактеризовано та проілюстровано основні види егоїстичної мотивації, мотиви збагачення та мотиви приналежності. Основну увагу приділено поєднанню альтруїстичного та егоїстичного компонентів мотиваційної складової у межах єдиної доброчинної дії та її ролі у реалізачії доброчинної діяльності.

Ключові слова: доброчинна діяльність, мотивачійна складова, альтруїстичні та егоїстичні мотиви.

\section{БЛАГОТВОРИТЕЛЬНАЯ ДЕЯТЕЛЬНОСТЬ В СОВРЕМЕННОЙ УКРАИНЕ: ОТ АЛЬТРУИСТИЧЕСКОГО ДО ЭГОИСТИЧЕСКОГО ДЕЙСТВИЯ}

\section{Е. А. Стрельникова, Н. А. Есина}

В статье рассмотрены особенности мотивационной составляющей благотворительной деятельности в современном украинском обществе. Приведена характеристика основных компонентов мотивационной составляющей благотворительности, альтруистичного и эгоистического, в современной Украине. Охарактеризовано и проиллюстрировано основные виды эгоистической мотивачии, мотивы обогащения и мотивы принадлежности. Основное внимание уделено сочетанию альтруистичного и эгоистического компонентов мотивационной составляющей и ее роли в реализащии благотворительной деятельности.

Ключевые слова: благотворительная деятельность, мотивационная составляющая, альтруистические и эгоистические мотивы.

\section{CHARITY ACTIVITY IN MODERN UKRAINE: FROM ALTRUISTIC TO SELFISH ACT}

\section{O. Strelnikova, N. Yesina}

The present article is devoted to the problems of charity activity and its motivation in modern Ukrainian society. The concept and essence of charity act are studied as primal component of charity activity, possibility of such investigation is proved in the article. As for authors, charity activity is a special kind of process, which consists of great amount of unitary charity acts. Unitary charity act as analyzed from the point of view of main activity theories of social science. According to these theories, charity activity and unity charity act can be

(C) О. О. Стрельнікова, Н. О. Єсіна, 2020 
researched as equal phenomena from the point of view of their motivation. The characteristic of the main personal reasons for taking part in charity activity in modern Ukrainian society is studied. Personal motivation is divided into altruistic and selfish reasons according to the modern approaches to considering types of motivation. Special attention is given to the selfish reasons, the opposite motivation to altruistic one, in modern Ukrainian society. There are two types of the selfish reasons are described in the article. The comparative analysis of the enrichment motivations and affiliation motivations is carried out and the main common and distinctive features of these reasons are determined in the article. It is said that motivation of the concrete charity act can be analyzed only in context of motivations unity, because they are both parts of the same social action. The potential of such further analysis is researched. The peculiarities of the process of motivation formation of charity activity in modern Ukrainian society are analyzed. The main characteristics of structural elements of charity motivation are described in the article on the basis of analysis of modern scientific literature. Special attention is given to the motivation aspect in social science. From the point of view of social science charity act is analyzed as democratic, selfless, and voluntary action. The social institute of charity in modern Ukrainian society gives equal possibilities, aimed at overcoming the barriers and constraints on the path to social well-being, which radically changes the existing state people and organizations in need. The results of the research can be used in the social science as a part of knowledge of motivation.

Key words: charity, charity activity, motivation component, altruistic and selfish reasons.

Постановка проблеми. Системна криза, що $\epsilon$ характерною для сучасного українського суспільства, приводить до суттєвих змін у соціальнополітичній, соціально-економічній, соціально-культурній та ін. його підсистемах. Поява нової вкрай небезпечної інфекційної хвороби наприкінці минулого року обумовила посилення стану нестабільності та невизначеності не лише у сучасній Україні, але й в світі в цілому. Загострення такого положення через стрімке розповсюдження коронавірусу Covid-19 країнами світу потребує пошуку нових форм розв’язання завдань, що постали, або актуалізацію старих, вже відомих шляхів вирішення проблемних ситуацій.

У сучасному українському суспільстві кількість осіб та організацій, котрі через певні причини опинилися у складних умовах життя, постійно зростає, що в свою чергу обумовлює звернення $з$ новою силою до реалізації усіх видів доброчинної діяльності. Набуває стрімкого поширення волонтерство, як складова частина доброчинності, бурхливого розвитку зазнає спонсорство, а разом 3 ними актуалізуються усі форми надання доброчинної допомоги. За таких умов можна сказати про необхідність дослідження мотиваційної складової такої допомоги, що лежить в основі прийняття рішення щодо залучення до доброчинної діяльності. 
Аналіз актуальних досліджень. Окремі теоретичні та практичні положення, плідні для подальшого дослідження мотиваційних особливостей реалізації доброчинної діяльності (та споріднених з нею явищ), наявні ще в роботах класиків соціально-політичної галузі наукового знання, зокрема у П. Бергера, О. Конта, К. Маркса, Р. Мертона, П. Сорокіна, тощо. Сучасні українські вчені, серед яких Д. Акімов, В. Бакіров, О. Балакірєва, Т. Бень, С. Буко, В. Полторак, І. Попова, Ю. Чернецький, О. Яременко та ін., намагалися теоретично осмислити соціально-культурний феномен доброчинності; дослідити доброчинність як вид соціальної діяльності; надати типологію історичних етапів еволюції доброчинності, тощо.

Проблема дослідження мотиваційної складової доброчинної діяльності привертала увагу багатьох вітчизняних та зарубіжних дослідників, зокрема К. Бюргойн, Н. Вайнілович, Л. Вестерлюнд, О. Кочнова С. Куц, Т. Лях, Н. Савранська, К. Уолкер, Л. Юрченко, Б. Янг та ін.

Незважаючи на значну кількість наукових праць із зазначеної проблематики, дослідження особливостей реалізації доброчинної діяльності 3 урахуванням ii мотиваційних складових й досі залишається недостатньо висвітленим.

Отже, мета даної статті полягає у дослідженні особливостей мотиваційної складової, що лежить в основі реалізації доброчинної допомоги у сучасному українському суспільстві.

Виклад основного матеріалу. Дослідницький інтерес до розуміння мотивів доброчинної діяльності притаманний багатьом гуманітарним наукам. У філософії та історії вважається, що головними спонукальними чинниками доброчинності виступають милосердя, альтруїзм, співчуття, острах покарання Божого. Представники соціально-політичної галузі знання в якості домінуючих виокремлюють мотиви прагнення до суспільного визнання та покращення іміджевої самооцінки. У соціальній психології наголошується на альтруїстичній мотивації доброчинців, а також трактування доброчинної міжособистісної взаємодії як специфічної «гуманітарної угоди». Деякі 
науковці-психологи вважають доброчинну діяльність проявом спонтанного та емоційно забарвленого запалу й допомоги за велінням серця й душі.

У межах даної статті інтерес до розуміння особливостей мотиваційної складової благодійної діяльності обумовлений здебільшого виявленням тих цінностей, що лежать в основі того чи іншого мотиваційного чинника. У фокусі нашої уваги знаходяться ціннісні установки, позиції індивідів, що знаходять свої відображення у мотивах, які спонукають до участі у доброчинній діяльності. Саме у такому аспекті дослідження мотиваційних чинників $\epsilon$ досить плідним для виявлення особливостей модернізації соціального інституту доброчинної діяльності у сучасному українському суспільстві.

В цілому чинники, що лежать в основі будь-якої діяльності, можна диференціювати, виходячи 3 їхньої моральної складової (Ilin, 2013). У відповідності до моральної цінності, на котрій грунтується доброчинність, прийнято розрізняти альтруїстичну та егоїстичну доброчинну дію або діяльність. Нагадаємо, що окрему дію, котра спрямована на надання добровільної та безкорисливої допомоги нужденним особам або організаціям, 3 метою виконання ними соціально-значущих функцій, ми розглядаємо як складову частину доброчинної діяльності. «Дія визначається як універсальний складник зовнішнього процесу діяльності. Соціальна дія одна 3 основних категорій соціології; людська діяльність розглядається як сукупність невизначеної кількості дій відокремлених індивідів, а кожна 3 таких індивідуально вмотивованих дій являє собою одиницю (першоелемент) діяльності. Виходячи з розуміння дії як складника діяльності, ми вважаємо за можливе розглядати доброчинність дещо ширше, ніж це прийнято у науковій літературі, а саме і як дію, що здійснюється добровільно та безкорисливо особами чи організаціями 3 метою надання матеріальної, фінансової, інтелектуальної та інших видів допомоги....» (Strelnikova, 2013, с. 75). Отже, якщо в основі діяльності 3 надання доброчинної допомоги лежить альтруїстичний мотив, то доцільно говорити про діяльність найвищого 
морального рівня. Люди починають реалізовувати альтруїстичну дію, спираючись на усвідомлення ऑii піднесеності, віру у цінність, власне, дії, виходячи з бажання удосконалити оточуючий світ та умови життєдіяльності нужденних осіб та організацій. Така дія взагалі, й доброчинна зокрема, не ставить на меті досягнення певних приватних корисних інтересів, чи здобуття різних видів капіталу, не може становити собою будь-яке поле для здійснення маніпулятивних технологій, тощо. Альтруїстичні дії широко описані у художній літературі, найвідоміші їхні приклади можна знайти у творах багатьох письменників. Зокрема, до зображення такої дії свого часу вдавався М. Горький під час створення образу Данко, який вирвав з грудей власне серце аби освітити шлях іншим людям та допомогти вийти зі згубного лісу.

Щодо наукової літератури, то, як вже було нами зазначено, в ній «благодійна діяльність часто пов’язується 3 альтруїзмом, таким принципом поведінки, коли благо інших людей стає вищим за власне. У соціології на альтруїстичній поведінці робив акцент О. Конт (2011), коли сперечався 3 економістами відносно того, який принцип необхідно покласти до основи науки про суспільство. Дослідник вважав, що саме альтруїзм, біологічний фундамент соціології, механізм індивідуальної мотивації, яка пояснюється інстинктами, лежить в основі доброчинної діяльності. Власне, сам термін «альтруїзм» (жити для інших) був уведений до соціології О. Контом, який вважав, що під впливом позитивізму суспільство розвивається у напрямку гуманістичних цінностей. Альтруїзм - зацікавленість у добробуті інших, він включає до себе бажання й прагнення надати допомогу іншим. Цей принцип становить універсальну формулу безкорисливої добродії, згідно якої благо іншої людини та вона сама значиміші, ніж власне «я» та власне благо» (2011, s. 99-100). В основу будь-якої доброчинної дії чи діяльності покладено принцип альтруїзму, що передбачає акт допомоги нужденним особам або організаціям без прояву егоїстичної мотиваційної складової. Однак, не зважаючи на те, що багато сучасних науковців віддають перевагу 
поясненню доброчинної діяльності через розуміння універсальності альтруїстичних мотивів людини (Ilin, 2013; Krucuk, 2017), стрімкого поширення набуває думка про те, що доброчинна допомога реалізується через наявність егоїстичної мотивації у доброчинних діях (Veblen, 1984; Kapska, 2005) або прихованої економічної чи політичної корисності такої соціальної поведінки (Clary, 1991).

Наявність егоїстичної складової неминуча у будь-якій мотивації, починаючи 3 моменту засвоєння та сприйняття людиною соціальних норм. Власне, 3 цього моменту відбувається знайомство особистості 3 методом заохочення та покарання, формується уявлення щодо набору санкцій, котрі застосовуються 3 метою профілактики та попередження поширення соціально несхвалюваної поведінки.

Звертаючись до класиків соціології, можна зазначити думку Т. Веблена, який наголошував на тому, що реалізації доброчинної діяльності завжди притаманна наявність як альтруїстичної, так і егоїстичної мотивації. «Це будь-якою мірою вірно, що багато суспільних діянь, які офіційно $є$ безкорисливими за духом, починаються та виконуються, безумовно, перш за все, з метою піднесення репутації чи грошової винагороди тих патронів, які опікуються цими діяннями... Це особливо справедливо... стосовно таких справ, як... наприклад, заснування університету, чи публічної бібліотеки, або музею...Коли жертвуються гроші на школи, бібліотеки, притулки, то будуються будівлі, що покриті коштовним матеріалом, із вікнами та баштами, які навіюють пересічному глядачеві думку про високу грошову престижність, а не про зручність» (1984, s. 291). На його думку (1984), задля збільшення поваги людей недостатньо лише володіти багатством, потрібно ще й зробити його очевидним.

На думку О. Круцюк, особам, що беруть участь у різних видах доброчинної діяльності, зокрема, у волонтерстві, «властива альтруїстична мотивація (має високу вираженість за шкалою «альтруїзм»), вони стараються принести користь іншим і часто це відбувається на збиток собі. Хоча 
егоїстична спрямованість у діяльності волонтерів є слабо вираженою, проте має місце. Це підтверджує тезу ... про те, що альтруїстична і егоїстична мотивація волонтерів може суміщатися і має виконувати свою роль на різних етапах здійснення волонтерської діяльності» (2017, s. 68). В цілому погоджуючись 3 думкою дослідника про наявність двох мотиваційних складових, егоїстичної та альтруїстичної, вважаємо за доцільне зазначити, що остаточний висновок щодо корисності чи безкорисності мотивів конкретної особи, яка залучена до такої діяльності, можна зробити шляхом співвіднесення цих складових між собою. У подальших власних спробах наукового осмислення мотиваційної складової добровільної та безкорисливої діяльності з допомоги нужденним О. Круцюк намагається диференціювати наявність цих факторів за часом залучення осіб до доброчинності. «Виявляється, що альтруїстичні мотиви є важливими на етапі формування первинної мотивації добровольців, які тільки починають свій шлях у цій сфері, водночас як егоїстична мотивація $\epsilon$ актуальнішою при підтримці у часовій перспективі добровільної участі» (2017, s. 75). Слід зауважити, що на нашу думку, егоїстична складова мотивації не є такою, що обумовлена лише тривалістю участі у доброчинній діяльності та сприяє їі усталеності. Адже відомі приклади, коли приватні корисні мотиви є поштовхом до прийняття рішення щодо участі у наданні доброчинної допомоги. Наявність та домінування таких спонукальних чинників може бути притаманна як особам, що тільки-но залучилися до доброчинної діяльності, так і тим, хто має значний досвід такої участі.

Широко поширеною у сучасній літературі $\epsilon$ думка про те, що егоїстична складова мотивації доброчинної діяльності є сильнішою, більш значущою за альтруїстичну (Veblen, 1984; Kapska, 2005; Clary, 1991). I справа тут навіть не у набутті та збільшенні кількості та сутності ресурсів соціального капіталу, що можуть проявлятися у наявності певного політичного чи економічного іміджу й авторитету, а у переслідуванні певної мети, котра полягає у реалізації отриманого нового досвіду задля подальшого 
існування та розвитку особистості-суб’єкта доброчинної діяльності (такий егоїстичний мотив часто має прояв у наступному формулюванні: «здобуття нових навичок та отримання досвіду, наявність нових знайомств, тощо»). Деякі з дослідників, зокрема А. Капська (2005), надають перевагу більш завуальованим формулюванням, називаючи конкретні види егоїстичної складової мотивації доброчинної діяльності, так званою, системою стимулівчинників. До такою системи, на думку А. Капською (2005), може входити досить велика кількість елементів, мотиваційних стимулів-чинників, починаючи від отримання знання про проблеми у суспільстві й закінчуючи здобуттям певного соціального статусу.

Цікавою у даному аспекті проблеми нам видається думка зарубіжного дослідника Е. Кларі. Оскільки, на його погляд (1991), участь у доброчинній діяльності обумовлена принаймні двома видами егоїстичної мотивації: мотивами збагачення (enrichment motivations) та мотивами приналежності (affiliation motivations). Перший вид мотивів не обмежується лише можливістю подальшого набуття матеріального чи фінансового багатства, але й передбачає наявність бажання отримувати та розвивати певні знання та навички, що можуть бути використаними у майбутньому 3 метою здобуття переваги. Мотиви ж приналежності, що становлять собою другий вид мотивації, мають в основі потребу суб’єктів доброчинної діяльності у спілкуванні та побудові соціальних зв'язків та відносин з іншими людьми, бажання почувати себе корисними, приналежати до престижної групи та отримати певний соціальний статус.

Висновки і перспективи подальших досліджень. Отже, теоретичний аналіз особливостей мотиваційної складової доброчинної діяльності засвідчив, що вона водночас складається з егоїстичного та альтруїстичного компонентів. Ці компоненти поєднуються різними способами та мають прояв у діапазоні від прагнення допомагати іншим, бути корисним суспільству до отримати певну користь для власної особи чи організації. Варто наголосити, що дійти висновку про егоїстичну чи альтруїстичну доброчинну дію в 
цілому, можна лише за допомогою співвіднесення іiі егоїстичного та альтруїстичного компоненту, за ступенем значущості одного з них у межах конкретної благодійної дії або діяльності. Однак необхідно визнати: від того, що соціально позитивна дія здійснюється переважно за корисними мотивами, соціальна цінність, власне, дії та значущість доброчинної діяльності знижується.

\section{ЛІТЕРАТУРА:}

1. Веблен, Т., 1984. Теория праздного класса: экономическое исследование институций. М.: Прогресс.

2. Ильин, Е., 2013. Психология помощчи. Эгоизм, альтруизм, эмпатия. СПб: Питер.

3. Капська, А., 2005. Підготовка волонтерів до соиіальної роботи: навч.-метод. посібник. Київ: Держсоцслужба.

4. Конт, О., 2011. Общий обзор позитивизма. М.: Книжный дом «ЛИБРОКОМ».

5. Круцюк, О. В., 2017. Особливості мотивів волонтерської діяльності. Украӥнський психологічний журнал. № 4. с. 65-77.

6. Стрельнікова, О.О., 2013. Доброчинна діяльність у вимірі теорії соціальної дії. Вісник Одеського начіонального університету. Т. 18. Вип. 3 (19). с. 72-76.

7. Clary, C., Snyder, M., 1991. A functional analysis altruism and prosocial behavior: The case of volunteerism. Prosocial behavior. Newbury Park, CA: Sage. p. 485-505.

\section{REFERENCES:}

1. Veblen, T., 1984. Teorya prazdnogo classa: econonmicheskoe issledovanye institytcyi. M.: Progress.

2. Ilin, Ye., Psyhologya pomochshy. Egoizm, altruism, empatyia. SPb: Pyter.

3. Kapska, A., 2005. Pidgotovka volonteriv do socialnoi robotu: navch.-metod. posybnuk. Kyiv: Dergslugba.

4. Kont, O., 2011. Obchshui obzor pozitivizma. M.: Knygnui dom «LYBROKOM».

5. Krucuk, O.V., 2017. Osobluvosti motuviv volonterskoi dyialnosti. Ukrainskyi psyhologichnui jurnal. № 4. c. 65-77.

6. Strelnikova, O.O., 2013. Dobrochunna dyialnict u vumiri teorii socialnoi dii. Visnuk Odeskogo nationalnogo universutety. T. 18. Вип. 3 (19). с. $72-76$.

7. Clary, C., Snyder, M., 1991. A functional analysis altruism and prosocial behavior: The case of volunteerism. Prosocial behavior. Newbury Park, CA: Sage. p. 485-505.

\section{Інформація про авторів}

Стрельнікова Олена Олександрівна - ст. викладач кафедри політології, соціології і культурології Харківського національного педагогічного університету імені Г.С. Сковороди; e-mail: elenastrelnikova85@gmail.com; ORCID: http://orcid.org/0000-0003-20427186.

Єсіна Наталія Олександрівна - доцент кафедри соціальної роботи і соціальної педагогіки, Харківського національного педагогічного університету імені Г.С. Сковороди, e-mail: esinanata81@gmail.com; ORCID: orcid.ory / 0000-0001-9546-418x.

Стаття надійшла до редакції: 06.11.2020 р. $\quad$ Прийнята до друку: 27.11.2020 p. 